\title{
A VÁLLALATI KOMMUNIKÁCIÓMENEDZSMENT KUTATÁSA - NEMZETKÖZI ÉS HAZAI PERSPEKTÍVÁBÓL
}

\section{CORPORATE COMMUNICATION MANAGEMENT AS A RESEARCH FIELD -} FROM LOCAL AND GLOBAL PERSPECTIVES

Jelen tanulmány témája a vállalati kommunikációmenedzsment, mint diszciplína kialakulása, elméletei, globális és lokális jellegzetességei, szerepe és trendjei a kutatások tükrében. Noha a vállalati kommunikációmenedzsment mára a menedzsmenttudományok egyik legdinamikusabban fejlődő területévé vált, önálló tudományterületként megjelenését tudományos nézetek ütközése övezte. A vállalatvezetésben ugyan nyilvánvaló volt, hogy e menedzsmenttevékenység kiemelten fontos az eredményességhez, azonban a vállalati kapcsolatok, a PR és a kommunikációmenedzsment egymáshoz való viszonyában értelmezési eltérések alakultak ki. Ennek következtében különböző fókuszok rajzolódtak ki a kutatásokban. A tanulmány készítésének módszere a nemzetközi és hazai szakirodalom rendező és értelmező áttekintése. A szerzők bemutatják a kommunikációmenedzsment fogalom megjelenését, értelmezését és a diszciplína kialakulását. Ezt követően ismertetik az eltérő kutatási súlypontokat az angol nyelvterületeken, egyes európai országok kutatásaiban és a hazai megközelítésekben. Kiemelik a vállalati kommunikációmenedzsmentnek a vállalati értékteremtésben betöltött szerepét, a mérhetőséget, az infokommunikációs technológia hatását és egyes specifikus feladatokat, valamint a vállalati kommunikációmenedzsment gyakorlati jelentőségét. A trendeket vizsgálva felrajzolják a jövő várható útjait.

Kulcsszavak: vállalat, kommunikációmenedzsment, elméletek, trendek

The topic of this review is the emergence of corporate communication management as a discipline, its theories, global and local characteristics, and its roles and trends in the light of research articles. Although today corporate communication management has become one of the most dynamically evolving fields of management, the first decades of the discipline were characterised by coexisting conflicting scientific theories. For the corporate management it was beyond doubt that corporate communication was elemental in the performance of the enterprises, however corporate PR, corporate relations and communication management had contradicting interpretations. These contributed to the appearance of distinct foci of international research. This review summarises international and Hungarian concepts. The authors demonstrate the emergence of the term of communication management, its interpretations and the development of the discipline. Next they present various foci of research in the UK and USA, in certain European countries and Hungary: the role of corporate communication management in value creation, its measurement, effects of info communication technology on it and some special areas. They overview the analyses of the trends and the projections for the near future: internationalisation, the effects of globalisation, mass media, digital media, social media; and the expected new challenges in corporate communication management.

Keywords: corporates, communication management, theories, trends

Finanszírozás/Funding:

A szerzők a tanulmány elkészítésével összefüggésben nem részesültek pályázati vagy intézményi támogatásban.

The authors did not receive any grant or institutional support in relation with the preparation of the study.

\section{Szerzők/Authors:}

Dr. Konczosné Prof. Dr. Szombathelyi Márta, egyetemi tanár, Széchenyi István Egyetem, (kszm@sze.hu)

Dr. Borgulya Ágnes, egyetemi magántanár, Pécsi Tudományegyetem, (borgulya.istvanne@ktk.pte.hu )

A cikk beérkezett: 2019.05.02-án, javítva: 2019.05.29-én, elfogadva: 2019.10.14-én.

This article was received: 02.05.2019, revised: 29.05.2019, accepted: 14.10.2019. 
$\mathrm{B}_{\mathrm{a}}^{\mathrm{a}}$ ár tanulmányunk bizonyos időrendiséget és egy-egy adott földrajzi területhez való kötődést választotta a kutatott témakörök mellett rendező elvnek, tisztában vagyunk azzal, hogy a földrajzi kötődés jelentősége egyre inkább csökken. A globalizáció és az internetre épülő információs forradalom következtében a kommunikációmenedzsment napjainkra globálissá vált. Az áttekintett folyamatok kezdetén azonban még világosabban elkülönültek területenként a kutatási súlypontok. Jeles kutatók is észak-amerikai és európai fogalomeltéréseket írtak le (Hallahan et al., 2007; Bentele \& Nothhaft, 2010). A globális jelenségek mellett számos, a kultúrától, a gazdasági, történelmi és társadalmi jellegzetességektől függő lokális jelenséget tudunk azonosítani.

\section{Az angolszász eredet és elméletek}

A vállalati kommunikációmenedzsment (VKM) tudománnyá az 1980-as években kezdett formálódni, angolszász/amerikai területeken, föleg az Egyesült Államokban és az Egyesült Királyságban. A VKM a 'corporate communication' fogalomköréből nőtt ki (van Riel, 1995). A kifejezéssel legkorábban 1992-es publikációkban találkozunk (White \& Dozier, 1992; Grunig, 1992). A VKM különböző elméleteit a gazdaság és társadalom elvárásai formálták. Igény keletkezett az érintettekkel való kommunikációban a különböző társadalmi, politikai, gazdasági és kulturális sajátosságok (például a nemzeti önállóság, a politikai rendszer, az értékek, a média szerepének stb.) figyelembevételére. Sürgetővé vált bizonyos érzékeny társadalmi kérdések proaktív kezelése, a kommunikáció egyszerüsítése, gyorsítása és a költségek minimalizálása.

Az új tudományterület erősödését nemzetközi szervezetek (International Communication Association, alapítás 1950; International Association of Business Communicators, alapítás 1970) felkaroló hozzáállása, majd fejlődését a tudományterület saját folyóiratainak megjelenése (Corporate Communications: An International Journal, 1996; Journal of Communication Management 1996; International Journal of Strategic Communication (IJSC), 2007) jelzi. Mivel a kommunikációmenedzsment alkalmazott tudomány, a kutatás a kezdetetktől fogva szoros kapcsolatban áll a napi gyakorlattal (Cornelissen, 2011).

A VKM összekapcsolódott a stratégiai menedzsmenttel, egy viszonylag új fogalommal és menedzsmentterülettel, mely az 1960-70-es évek “terméke” (Drucker, 1969; Minzberg, 1973). A stratégiai megközelítés a kommunikáció kereteinek újraértelmezését is igényelte. A kommunikáció- és vezetéstudomány-kutatók eltérő tudományterületi háttere fogalmi zavarokat eredményezett. Kezdetben letisztulatlan volt a fogalomjelölés az angol nyelven belül is, a 'corporate communication managing system', 'strategic communication managing system' (Varey, 1998; Varey \& White, 2000), 'strategic communication' megközelítőleg azonos tartalmakat jelöltek.
Egy évtized múltán a "strategic communication" pontos definiálását neves nemzetközi szerzőcsoport vállalta fel (Hallahan et al., 2007) a tekintélyes IJSC legelső számának hasábjain. A szerzők egy szervezetnek a missziója megvalósitását szolgáló, céltudatos kommunikációját tekintik stratégiai kommunikációnak. Megállapításuk lényege:

- a stratégiai kommunikáció menedzsmentfunkció,

- célja a szervezeti küldetés, a szervezeti célok elérésének támogatása,

- a "stratégiai” jelző erősen kötődik a menedzsment modernista megközelítéséhez, amely a felső vezetés gazdasági és racionális céljait állítja a középpontba,

- a hadviseléshez kötődő eredeti jelentés következtében a "stratégia" szóhoz a hatalom, az erőszak, a legyőzés, a célcsoport manipulációja asszociációk kapcsolódnak, így a stratégiai kommunikáció negatív konnotációt kapott.

A stratégiai kommunikáció menedzsmentje - szintén az IJSC szerint - számos tudományterület foglal magában, mint például a vállalati és menedzseri kommunikáció, a szervezeti kommunikáció, a közönségkapcsolatok, a marketingkommunikáció, a közösségi marketing, a nemzetközi kapcsolatok, a nyilvános diplomácia és egyes üzleti tevékenységekre szükített kommunikációs területek.

Nehezen váltak szét egymástól a VKM (Corporate Communication Management: CCM) és a Public Relations (PR) fogalomterületek. Ennek oka részben James Grunig sokak (pl. Bentele, 1996) által átvett definíciója volt: "Public relations, therefore, is the management of communication between an organization and its publics" (Grunig \& Hunt, 1984, p. 8). Eszerint a PR a kommunikáció menedzsmentje egy szervezet és annak nyilvánossága között. Ez az állítás helytálló. Nem azt mondja ki, hogy a kommunikációmendzsment a PR-ral lenne azonos, hanem azt, hogy a PR tevékenység a kommunikáció menedzselését magában foglalja. Az azonban, hogy a Grunig \& Hunt (1984) müvet idéző szerzők (pl. Tench \& Yeomans, 2017) egyenlőségjelet tettek a két fogalom közé, a VKM félreértelmezését és a PR-ral összemosását vonta maga után.

Ebből az értelmezésből eredt az a felfogás, hogy a kommunikációmenedzsment számára a legfontosabb feladat az adott szervezet és a társadalom közti kapcsolat megteremtése, a szervezetnek/vállalatnak a társadalom általi elfogadtatása (Van Ruler \& Verčič, 2005; Moreno et al., 2010; Konczosné, 2013).

A stratégiai kommunikáció és a kommunikációmenedzsment egymás mellett váltak kulcsfogalommá és öszszekapcsolódva is megjelennek: 'strategic communication management' (Andersson, 2019). Uralkodó témáikat foglalja össze az 1. táblázat. 
1. táblázat $A$ vállalatikommunikáció-elméletek uralkodó témái

\begin{tabular}{|c|c|c|c|c|c|}
\hline Témák & $\begin{array}{c}\text { Grunig (1984- } \\
\text { 2002) } \\
\end{array}$ & Argenti (2003) & Van Riel (1992) & Bruhn (2003) & Cornelissen (2008) \\
\hline $\begin{array}{l}\text { Kommunikációme- } \\
\text { nedzsment fogalma }\end{array}$ & $\begin{array}{l}\text { A PR / kommuni- } \\
\text { káció } 4 \text { modellje } \\
\text { (kétirányú, szim- } \\
\text { metrikus, norma- } \\
\text { tív modell) }\end{array}$ & $\begin{array}{l}\text { Vállalati kommunikáció } \\
\text { mint menedzsmentfunkció }\end{array}$ & $\begin{array}{l}\text { Vállalati kommunikáció } \\
\text { mint értékes menedzseri } \\
\text { eszköz }\end{array}$ & $\begin{array}{l}\text { Vállalati kommuniká- } \\
\text { ció mint tervezési és } \\
\text { szervezeti folyamat a } \\
\text { különböző kommuni- } \\
\text { kációs tevékenységek } \\
\text { integrálására }\end{array}$ & $\begin{array}{l}\text { Vállalati kommunikáció } \\
\text { mint menedzseri keret a } \\
\text { kommunikációs tevékeny- } \\
\text { ségek irányítására, továbbá } \\
\text { technikai eszközkészlet }\end{array}$ \\
\hline Célcsoport & $\begin{array}{l}\text { Külső és belső } \\
\text { célcsoportok }\end{array}$ & Választók & $\begin{array}{l}\text { Külső és belső célcso- } \\
\text { portok }\end{array}$ & $\begin{array}{l}\text { Külső és belső célcso- } \\
\text { portok }\end{array}$ & $\begin{array}{l}\text { Stakeholders (érdekgaz- } \\
\text { dák, érdekeltek) }\end{array}$ \\
\hline Vállalati identitás & $\mathrm{n} / \mathrm{a} *$ & \multirow{2}{*}{$\begin{array}{l}\text { Identitás (vizuális), imázs } \\
\text { (a választókban kialakult } \\
\text { kép) és hírnév (immateriá- } \\
\text { lis vagyon) mint a vállalati } \\
\text { kommunikáció alapfunk- } \\
\text { ciója }\end{array}$} & $\begin{array}{l}\text { A vállalat önképe, visel- } \\
\text { kedésen, kommuniká- } \\
\text { ción és szimbólumokon } \\
\text { keresztül továbbítható }\end{array}$ & $\begin{array}{l}\text { Identitás, amelyet a } \\
\text { vállalatnak az összes } \\
\text { kommunikációs csa- } \\
\text { tornán való folyamatos } \\
\text { megjelenése hoz létre }\end{array}$ & $\begin{array}{l}\text { Vállalati és szervezeti } \\
\text { identitás, mint amelyek } \\
\text { szorosan egymásra épül- } \\
\text { nek és szoros kapcsolatban } \\
\text { állnak egymással }\end{array}$ \\
\hline Hírnév & $\mathrm{n} / \mathrm{a} *$ & & $\begin{array}{l}\text { Hírnév mint immateriá- } \\
\text { lis vagyon }\end{array}$ & $\mathrm{n} / \mathrm{a}^{*}$ & $\begin{array}{l}\text { Az érdekelt feleket ma- } \\
\text { gában foglaló percepció } \\
\text { (jövőre vonatkozó elkép- } \\
\text { zelés) }\end{array}$ \\
\hline $\begin{array}{l}\text { Belső kommuni- } \\
\text { káció }\end{array}$ & $\begin{array}{l}\text { Szimmetrikus } \\
\text { modell alkalma- } \\
\text { zása } \\
\end{array}$ & $\begin{array}{l}\text { Kapcsolódva a felső veze- } \\
\text { téshez és a stratégiához }\end{array}$ & $\begin{array}{l}\text { A munkavállalók moti- } \\
\text { válása, bizalom megte- } \\
\text { remtése }\end{array}$ & $\mathrm{n} / \mathrm{a} *$ & $\begin{array}{l}\text { A cég tagjai mint belső } \\
\text { stakeholderek }\end{array}$ \\
\hline $\begin{array}{l}\text { A kommunikáció } \\
\text { funkciója }\end{array}$ & $\begin{array}{l}\text { Menedzser/tech- } \\
\text { nikus dichotómia } \\
\text { Az integrált } \\
\text { kommunikáció } \\
\text { fogalma }\end{array}$ & $\begin{array}{l}\text { Középút a centralizált és } \\
\text { a decentralizált struktúra } \\
\text { között; A CEO-ig terjedő } \\
\text { beszámolási vonal }\end{array}$ & $\begin{array}{l}\text { A marketingkommu- } \\
\text { nikáció, a szervezeti } \\
\text { kommunikáció és a me- } \\
\text { nedzsmentkommunikáció } \\
\text { magában foglalása }\end{array}$ & $\begin{array}{l}\text { A vállalati kommuni- } \\
\text { kációs tevékenységek } \\
\text { integrálása a tartalom, } \\
\text { a formális szempontok } \\
\text { és az időzítés szem- } \\
\text { pontjából }\end{array}$ & $\begin{array}{l}\text { A szervezeti struktúrákba } \\
\text { való integráció helyett a } \\
\text { megfelelő irányítási folya- } \\
\text { matok összehangolása }\end{array}$ \\
\hline
\end{tabular}

Forrás: Hübner 2007 alapján saját szerkesztés

*n/a (not available) - nem áll rendelkezésre

2000 első évtizedének végére letisztulnak a vállalati kommunikációmenedzsment fontos ismérvei és hatásai. Ezek szerint a VKM

- $\quad$ stratégiai nézőpontot követ (Hallahan et al., 2007; Sriramesh \& Verčič, 2009),

- tervezési és értékelési folyamatot is magában foglal, kulcselemei a stratégia, a kommunikátorok és célcsoportjaik, a források, az értékelésére és optimalizálásra épülő folyamatirányítás (Mast, 2002),

- integráltan kezeli a különböző kommunikációs célokat és feladatokat ( $\mathrm{pl}$. marketing PR, vállalati PR) (Cornelissen 2008),

- koordinál (Varey 1998),

- stakeholder orientáltan interaktív,

- megszünteti a szétaprózottságot (fragmentáltságot) a vállalat kommunikációjában (Van Riel \& Fombrun, 2007),

- értéket teremt (a német szerzők) és

- menedzsmentszinten müködtetik (Steyn 2003; van Riel \& Fombrun 2007; Cornelissen 2008).

Nyilvánvalóvá válik a kommunikációmenedzsment súlya a vállalati küldetés és stratégia megvalósításában.

Az angolszász területekről kiinduló VKM, mint vezetési funkció, rohamos fejlődést mutat világszerte, beleértve az ázsiai országokat (Kínát, Indiát, Pakisztánt, Thaiföldet, Malajziát, Dél-Koreát, Singapore-t, Hongkongot), sőt Latin-Amerikát és Afrikát is. Ennek következtében további tudományos mühelyek, megközelítések, elméletek is formálódnak. Ezeket az alábbiakban mutatjuk be.

\section{Az észak-európai, a német nyelvü és a kelet- európai országok mühelyei}

Az angolszász szemlélet megérintette a német nyelvű és az európai északi országok kutatóit, ahol a vállalati extern és intern kommunikáció kutatásának kiterjedt és mély előzményei voltak már (Muhr, 1988; Berger et al., 1989; Witt, 1993; Bartsch, 1994; Bungarten, 1994a; 1994b; Derieth, 1995; Birker, 1998; Van Riel, 1992; Cornelissen 2008). A PR-kutatás terén Lipcsében Günter Bentele (1996), az integrált vállalati és marketingkommunikáció művelésében Baselben Manfred Bruhn (1993, 2003) váltott ki nemzetközi visszhangot. A holland Cees van Rielnek és Joep Cornelissen-nek köszönhetően Rotterdam a vállalati kommunikáció és hírnévmenedzsment (corporate communication, reputation management) kutatásának észak-nyugat-európai központjává vált (Cornelissen \& Lock, 2001; Cornelissen \& Wim, 2003). Koppenhágában Lars Thoger Christensen munkatársaival müvek sokaságával járult hozzá a vállalati kommunikáció megismeréséhez (Christensen, 1994a; Christensen, 1994b).

A fenti előzményekre építve német nyelvterületen a 2000-es évek elejétől egyre több kutató fordul a VKM téma felé. Ebben nagy szerepe van az ún. paradigmaváltásnak, az értékorientált menedzsment terjedésének. A "német iskolák" a PR kontra kommunikációmenedzsment vitában világos és egyértelmü álláspontot fogadnak el. Ansgar Zerfass definícióját követik, aki a vállalati kommunikációt (Unternehmenskommunikation) fófogalomnak tekinti. A vállalati kommunikáció magában foglal 
minden kommunikációs folyamatot, amely a vállalat belső és külső környezete között játszódik (Zerfass, 1996).

Következésképpen a PR a vállalati kommunikáció egy területe, menedzselése a VKM hatáskörébe tartozik. Claudia Mast (Harlow, 1976-ra utalva) a PR-nak a következő funkciókat tulajdonítja:

- a vállalat és célcsoportjai közötti kölcsönös megértés,

- a goodwill megteremtése és fenntartása, információközvetítés,

- bizonyos társadalmi célok elérése, így az üzleti célok és a társadalmilag felelős magatartás közötti feszültség kiegyenlítése (Mast, 2002).

A VKM tartalmazza e funkciókat is, de ennél átfogóbb, tágabb fogalom: „,kommunikáció révén megvalósuló menedzsment és a kommunikáció menedzselése" (Mast, 2002, p. 16). Ez azt jelenti, hogy a VKM körébe tartozik a kommunikációs stratégiák elkészítése, azok gyakorlati megvalósítása, a kommunikációs stratégia végrehajtása folyamatának, részterületeinek, lépéseinek kidolgozása, és a folyamatok nyomon követése. A menedzsmenthez az idővel, a környezettel, a pénzügyi és más forrásokkal való gazdálkodás is hozzátartozik. A kommunikációmenedzsment, mint diszciplina a vállalati kommunikációnak a stratégiai menedzsmentben betöltött szerepét hangsúlyozza. A VKM-nek ez az értelmezése megnyitotta az utat a vállalati kommunikáció, a VKM és ezek egyes területeinek rendszerszerű megközelítése és vizsgálata előtt.

Az ezredforduló óta eltelt közel két évtized alatt elméleti keretek és tudományterületi kérdések (Mast, 2002; Oelert, 2003) éppúgy foglalkoztatták a szerzőket, mint a gyakorlati müködésre és hasznosíthatóságra vonatkozó ismeretek megszerzése (Klewes, 2005; Biesiadecka, 2009; Röttger et al, 2013). Az empirikus kutatások egyaránt fókuszálnak német vállalatok kommunikációmenedzsmentjének feltárására és nemzetközi összehasonlításokra.

Az új irányzat erősödésével Stuttgart és München (Claudia Mast és Simone Huck), Lipcse (Ansgar Zerfass, Günter Bentele, Juliane Kiesenbauer), Basel, Zürich és St. Gallen (Manfred Bruhn, Peter Szyszka és Boris Lyczek, Miriam Meckel, Beat F. Schmid) váltak a kommunikációmenedzsment-kutatás kiemelkedő központjaivá a német nyelvterületen. A svájci Institut für Medien- und Kommunikationsmanagement der Universität St. Gallen évtizedekre meghatározó kutatóhely lett.

A 2005-2007-es időszakban robbanásszerüen megnőtt a kutatási érdeklődés a téma iránt. Schmid \& Lyczek (2006) tanulmánykötete részletesen elemzi a kommunikáció vállalati értékteremtő szerepét, a kommunikációmenedzsment egyes területeit, bemutatja annak szerepét a vállalati kommunikáció egyes speciális feladataiban (a válságkommunikációban, a változások kommunikálásában, az issues-menedzsmentben), és ismerteti a kommunikáció-kontrolling lényegét. A PR a svájci szerzők értelmezésében is a vállalati kommunikáció egy területe, éppúgy, mint a munkatársakkal folytatott belső kommunikáció, a kapcsolati, vagy a pénzügyi kommunikáció. A PR menedzselése a VKM részfeladata. Bentele és Will tanulmánya is leszögezi: „Ma a Public Relations-t nemzetközileg túl- nyomórészt a szervezetek kommunikációmenedzsmentje részének tekintik" (Bentele \& Will, 2006, p. 151).

Manfred Piwinger és Ansgar Zerfass (2007) a kommunikációmenedzsment sokrétűségére összpontosít, az értékteremtő szerepen túl előtérbe kerülnek egyes etikai és pszichikai kérdések, a bizalom és a hitelesség, továbbá a szervezeti kultúra, a kommunikációs eszközök, a vezetési kompetenciák és nemzetközi sajátosságok is.

Bár az angol nyelven író szerzők a kommunikációmenedzsment elnevezés helyett továbbra is vállalati (corporate communications) (Christensen et al., 2008), vállalati stratégiai vagy integrált kommunikáció elnevezéseket használnak ("strategic approach to the management of corporate communication", "integrated communication"), a taglalásból egyértelmü, hogy ezeket a német irodalomban a VKM fogalommal (Kommunikationsmanagement) azonos jelentésünek tekintik (Siano et al., 2013). Hangsúlyozzák, hogy a vállalati kommunikáció feladata a szervezet valamennyi kommunikációs megnyilvánulásának egyetlen koherens entitássá szervezése (Christensen et al., 2008, p. 3).

A kommunikációmenedzsment mint tudományterület müvelése terjed, és Közép-Kelet-Európában is követőkre talált. A "Communication Management Review (CMR)" http://www.commreview.hr Horvátországban 2016 óta megjelenő, az Edward Bernays College of Communication Management által kiadott folyóirat. Az oktatási intézmény 2015-ben, majd 2017-ben szervezett nemzetközi kommunikációmenedzsment fóruma elsősorban horvát vállalatok és intézmények kommunikációs gyakorlatát mutatja be (Verčič et al., 2015).

\section{A kommunikációmenedzsment hazai kutatása}

$\mathrm{Az}$ alapvetően a német iskolákhoz köthető VKMszemlélet a hazai kutatásban a 2000-es évek első évtizedében jelenik meg. A terület művelésének jelentős állomása az MTA IX. Osztálya Gazdálkodástudományi Bizottsága (korábban Vezetés- és Szervezéstudományi Bizottsága) keretében létrejött Kommunikációmenedzsment Albizottság (2012-től Munkabizottság) megalakulása 2008-ban. Ez a szerveződés teremtett fórumot a VKM területét müvelő kutatók és vállalati szakemberek rendszeres találkozására, és épített ki kutatási kooperációt a címszó alá tartozó témák kutatására. A Munkabizottság tagjai egyrészt a hazai felsőoktatás gazdasági képzőhelyeinek az oktatói, másrészt nagyvállalatok és számos közép- és kisvállalat kommunikációs szakemberei.

A Munkabizottság tíz éves fennállása óta 14 konferencia keretében foglalkozott a VKM időszerü kérdéseivel. A kommunikációmenedzsment feltárásában rendező elvet jelentettek a vállalattípusok: a nemzetközi nagyvállalatok, a kis- és középvállalatok, a startup vállalkozások, az ipari klaszterek. Több konferencia speciális kommunikációs problémákkal (a válságkommunikációval, a kultúraközi kommunikációval és az etikusság aspektusával) foglalkozott. Kiemelendő a Munkabizottság tagjainak a nemzetközi és kultúraközi kommunikációmenedzsment területén végzett kutatása (Konczosné, 2008; Borgulya, 2010; Primecz et al., 2011; Borgulya, 2011; Ablonczyné Mihályka \& Tompos, 2011; Hidasi, 2011; Falkné Bánó, 2011; Bajzát, 2011; Bor- 
gulya, 2014; Borgulya et al., 2015). További témák voltak a vállalati kommunikáció egyes területei (a munkatársakkal folytatott kommunikáció, az oktatási intézmények és a vállalatok közti kommunikáció a duális képzés keretében, a közszolgálati intézmények kommunikációja), az eszközök (az „új média”, a korszerü infokommunikációs eszközök hatása és a VKM). A Munkabizottság az előadásokból készült tanulmányokból két tanulmánykötetet jelentetett meg (Borgulya \& Deák, 2011; Borgulya \& Konczosné, 2017).

A Munkabizottság tagjai közös kutatási projektjeik keretében a nemzetközi nagyvállalatok kommunikációmenedzsmentjét (Borgulya et al., 2015; Konczosné et al., 2016), az ipari klaszterek kommunikációmenedzsmentjét (Borgulya \& Kovács, 2018; Borgulya \& Balogh, 2019) és a humánerőforrás-menedzsment kommunikációs vetületeit (Borgulya et al., 2016) vizsgálták.

A hazai vállalatikommunikáció-kutatás felsőoktatási projektek keretében is zajlik: ilyen például a Miskolci Egyetem 2010-ben indult projektje (Dobos (szerk.), 2012; Magnuczné, 2016). A tanulmányok igen változatos problémaköröket fognak át (intern kommunikáció, PR, etikai, interkulturális és lingvisztikai sajátosságok).

\section{A kommunikációmenedzsment fő kutatási témái és gyakorlati jelentősége}

$\mathrm{Az}$ új évezred első évtizedében a vállalati kommunikáció korábban fel nem ismert funkciói, lehetőségei kerülnek előtérbe. Bár továbbra is jelentős teret kap a monográfiákban az extern és intern vállalati kommunikáció határainak összemosódása, a stratégiai fókuszálás, az egyre szerteágazóbb kommunikációs tevékenységek integrálása (Christensen et al., 2008), az „új média” hatása, (Meckel \& Schmid, 2008; Maas \& Stahl, 2008), egyre több mü foglalkozik az értékteremtés, a kommunikáció okozta költségek megtérülése, a tervezhetőség és optimalizálás, a mérhetö eredmények kérdésével, továbbá a speciális funkciókkal.

\section{A kommunikációmenedzsment fő kutatási témái}

$\mathrm{Az}$ értékorientált menedzsmentszemlélet, a stakeholder központú vezetés átértékelte a kommunikáció jelentőségét. A mindent átható, de nehezen megragadható tevékenység néhány év alatt a vállalati pénzügyi menedzsmenttel, az emberierőforrás-menedzsmenttel vagy a környezetmenedzsmenttel egyenrangú menedzsmenttevékenységgé vált.

\section{A vállalati értékteremtés és a kommunikációmenedzsment}

A kommunikáció önmaga nem képes nyereséget termelni, de jelentős hatással van a hozam létrejöttére. Annak következtében, hogy képes a vállalat iránti bizalmat erősíteni, hogy tudást közvetít, hogy befolyásolja a magatartást, (például a fogyasztást), hogy motivál, hogy hatással van a hírnévre, a minősége elemi fontosságú. A kommunikáció a vállalat immateriális vagyonképző eleme. Ez a felismerés új kihívást hozott a menedzsment számára. Megnőtt az igény a kommunikáció irányíthatóságára, és elvárássá vált, hogy világosan ellenőrizhető legyen, hogy milyen mértékben járul hozzá a kommunikáció a vállalat stratégiai és pénzügyi cél- jainak megvalósításához. A kommunikáció eredményeként létrejött imázs és a hírnév tőkejelleggel bírnak, a kommunikáció menedzsmentje, mint intangibilis töke menedzsmentje tehát vállalatvezetési feladat (Schmid \& Lyczek, 2006). A szerzőpáros által kidolgozott modellben a kommunikáció hármas szerepet tölt be az értékteremtés folyamatában: egyrészt a kommunikációnak köszönhetően a fogyasztó észleli a terméket, másrészt külső és belső dialógus keretében internalizálódnak a stakeholder értékek és érdekek a vállalati cselekvésben. Ennek során kölcsönös előnyöket biztosító módon integrálódik a vállalat a környező társadalomba. Harmadsorban a vállalati céloknak megfelelöen alakított kommunikációs helyzetek révén tudatosul a vállalat a stakeholderek csoportjaiban (Schmid \& Lyczek, 2006, p. 129). A kommunikáció értékteremtő szerepe számos további német nyelvü tanulmány tárgya (Mast, 2005b; Schmid \& Meckel, 2008), és ez a felfogás tükröződik Borgulya (2010) monográfiájában is.

\section{A kommunikációmenedzsment eredményességének mérése}

A vállalat intangibilis értékeinek reflektorfénybe kerülése szükségszerüen magával hozta az eredményességmérés számszerüsítésének fejlesztését. Ebben a folyamatban játszik szerepet a kommunikációkontrolling (Zerfass \& Pfannenberg, 2005; Mast, 2005a). A Scorecardoknak a kommunikáció területére adaptálása új lehetőségeket kínált. Tanulmányok, könyvek sokasága foglalkozik a kommunikációkontrolling lényegével, alkalmazásával és vállalati eredményeivel (Zerfass \& Pfannenberg, 2005; Lautenbach \& Sass, 2005; Pfannenberg, 2005; Esch et al., 2016). Ígéretes rugalmas irányítási eszközként tünt fel a Corporate Communications Scorecard (Zerfass, 2005), és szemléletesen mutatta be az összefüggéseket a Communication Scorecard (Hering et al., 2004; Schuppener, 2005). Mutatószámokra épült a CommunicationControlCockpit (CCC) is (Rolke, 2005). Indexek, koefficiensek képezik több további ezen időszakban megjelent tanulmány tárgyát is (Wiedman et al., 2005; O’Gorman \& Pirner, 2005; Rolke, 2007; Porák et al., 2007). Az eredményesség mérését szolgáló módszerek a hazai szaksajtóban is ismertté váltak (Borgulya, 2008; Szőrös, 2008; Szőrös, 2010a; Szőrös, 2010b).

Nem találtunk azonban statisztikailag értékelhető beszámolókat arra vonatkozóan, hogy milyen mértékben terjedtek el és mennyire eredményesek a kommunikációmenedzsment fenti mutatószámokra épülő tervezési és értékelési módszerei. Léteznek ugyan egyedi eseteket bemutató tanulmányok, mint a DaimlerChrysler Classic-nál használt Scorecard módszer (Röhrig, 2005), vagy a kommunikációkontrolling a Mercedes-Benz-nél (Liebl, 2003). Ezek sikeres alkalmazásról szólnak, de nagyon nagy időráfordításról is tanúskodnak (Röhrig, 2005).

\section{A tanuló szervezetek kommunikációjának menedzsmentje}

A tudásmenedzsment, illetve a tanuló, a tudásszervezetek és a kommunikációmenedzsment kapcsolatával foglalkozó tanulmányok jelentős hányada a tudáskommunikáció egyénfüggő jellemzőivel foglalkozik. A vizsgálatok tárgya többek között 
- a közvetlen személyközi (face-to-face) kommunikáció és a munkaerő produktivitása (Salis \& Williams, 2008),

- a kommunikációs szorongásban szenvedők és a tudásmenedzsment-funkciók (Crawford \& Stronthkirch, 2006),

- a szakemberek tudásbeli aszimmetriája és a tudáskommunikáció hatékonysága (Eppler, 2007),

- a kommunikáció stílusa és a tudásátadás (Gümüs, 2007).

Ezek a kutatási eredmények rámutatnak arra, hogy az emberi tényezőket, a kognitív és lelki folyamatokat odafigyelően tervező és folyamatosan monitorozó kommunikációmenedzsment jelentős mértékben javíthatja a tudásmenedzsment eredményességét.

\section{Az innováció kommunikációjának menedzsmentje}

Mast et al. (2005) az innovációkommunikációt a szervezet és a stakeholderei közötti olyan ,szimbolikus interakcióként" értelmezi, ,,amely új termékekkel, szolgáltatásokkal és technológiákkal foglalkozik" (Mast et al., 2005, p. 4).

A tudásmenedzsment és az innovációmenedzsment egymással szorosan összefüggő tevékenységek. "A tudás megosztása az innováció legfontosabb összetevője" (Bhirud et al., 2006 idézi Murat Gümüs, 2007, o.n.). A tudáscserében viszont az innovációkommunikáció játszik döntő szerepet (Könighofer, 2013). Ahogy változnak az innováció terén a feladatok, úgy jelentkeznek új és újabb információ- és tudásigények. A tudáskommunikáció tehát az innováció kommunikációjának építőköve.

Az innovációkommunikáció kutatása egyaránt jelentőséggel bír az intern és az extern kommunikáció szerepének megismerésében. Mindkét terület széles körben reprezentált a szakirodalomban (Mast et al., 2005; Pfeffermann \& Hülsmann, 2011; Mast, 2009; Gelbmann \& Vorbach, 2007;. Zerfass \& Möslein, 2009; Cronquist et al., 2006). A szakirodalomból az innováció kommunikációjának bizonyos személyiségi és intézményi előfeltételei is kirajzolódnak (Talke, 2005).

A német szakirodalom egyaránt bővelkedik elméleti keretek tisztázásában és empirikus kutatásokban (Huck, 2007; Zerfass \& Huck, 2007, Zerfass \& Nadin, 2008; Zerfass, 2009; Zerfass \& Möslein, 2009; Nelke, 2016). Huck-Sandhu és Hassenstein (2013) vállalati eseteken keresztül mutatja be a meghatározó tényezőket és a perspektívákat. Empirikus kutatások arra a következtetésre jutnak, hogy bár az innováció többlépcsős folyamat, amely strukturális, folyamatszempontból is vizsgálható, a megértést és a tudás áramlását az emberi interakciók biztosítják (Beckett \& Hyland, 2009).

\section{Az új média, a digitális kommunikáció és a vállalati} kommunikációmenedzsment

Az infokommunikációs technológia dinamikus fejlődése merőben új lehetőségeket kínál a vállalati kommunikáció számára. Az újítások mind a hardverek, mind a szoftverek, az alkalmazások terén gyors tempóban követik egymást. A digitalizás a kommunikációmenedzsment valamennyi területét áthatja. A tervezéshez például webalapú, 3D Web és Semantic Web technológiát kínálnak kutatók, amelyek segítik információk összegyüjtését és elemzését a tervező munkához (Lesko \& Hollingsworth, 2011; Mast \& Fiedler, 2004; Hoffmann, 2001).
A kommunikációmenedzsment terén végzett kutatások egyik jelentős központja az európai PR-oktatók és -kutatók szervezete, az EUPRERA. Közremüködésével végzik el 2007 óta évente az European Communication Monitor (ECM) kutatásokat, melyek többek között a rohamosan változó kommunikációs csatornákra, az online kommunikációra és a közösségi médiára, mint a kommunikációs szakemberek eszközeire fókuszálnak. A trendek egyértelműen mutatják

- a kommunikációs csatornák/eszközök rohamos változását/fejlődését,

- a digitális fejlődéssel, a közösségi médiával és az információáradattal való megbirkózás stratégiai jelentőségét,

- az interaktív csatornák jelentőségének a növekedését (hálózatok, videók, közösségi platformok, blogok),

- a www befolyásának növekedését, és ezáltal a globális médiának a vállalatok részéről (is) a célcsoportok elérésének legfontosabb eszközzé válását.

Az ECM-kutatások eredménye szerint a kommunikációs szakemberek két legfontosabb feladata a közeljövőben egyrészt a digitális fejlődéssel, a 'social webbel' való megbirkózás, másrészt az üzleti stratégia és a kommunikáció összekapcsolása lesz (Konczosné et al., 2015; Zefass et al., 2018).

\section{Nemzetközi és kultúraközi vállalati kommunikációmenedzsment}

A kultúraközi és nemzetközi vállalati kommunikáció sokrétű jelensége évtizedek óta sok kutatást ösztönzött. (Kirchner, 2001; Ybema \& Hyunghae, 2009).

Új fejezetet nyitott azonban a vállalati stratégiát figyelembe vevő kommunikációmenedzsment alkalmazása nemzetközi és kultúraközi feladatok irányítására. A stratégiák és az operatív végrehajtások rendszerbe foglalása, az eredményesség monitorozása német kutatók nevéhez kötődik (Johanssen, 2001; Andres, 2004; Huck, 2005a; Huck, 2005b; Huck, 2006; Huck, 2007; Klare, 2010). Andres és Huck részletesen feltérképezik az alkalmazható stratégiákat és a hozzájuk tartozó operatív lépéseket is.

Primecz és társai (2011) menedzsment-esettanulmányai tágabb összefüggésekbe helyezik a kommunikáció kérdését, és több ország, kultúra vonatkozásában mutatnak be tanulságos eseteket, az elméleti hátteret is közvetítve. A hazai irodalomban Borgulya (2010, illetve 2014) foglalja össze az alapvető jellemzőket. A nemzetközi vállalatoknak sarkalatos kérdése a nyelvpolitikájuk kialakítása. A ,nyelvmenedzsment” fogalom ezt a problémakört jelöli (Feely \& Harzing, 2003). A főhadiszállás és leányvállalatainak nyelvi kapcsolata, a munkanyelvek megválasztása, az angol nyelv közvetítő nyelvként használata számos tanulmány tárgyát képezi (többek között: Hildebrandt \& Liu, 1991; Vaara et al., 2005; Park \& Vanhonacker, 2007; Luo, 2007; Harzig \& Feely, 2008; Harzing et al., 2011; Zhang et al., 2018).

2000 óta valósággal divattémává vált a nemzetközi kommunikációs problémák kutatása. E szakirodalmak közül kiemelkedik Hugh M. Culbertson \& Ni Chen (1996) és Shriramesh Krishnamurthy \& Dejan Verčič (2003). Müveikben közös, hogy a Public Relations (PR) talajából nőnek ki. 
Egy, a nemzetközi vállalatok országhatárokon átívelő belső kommunikációjának menedzsmentje témában folytatott kutatás (Borgulya et al., 2015; Konczosné et al., 2016) kimutatta, hogy a kommunikációs szakemberekre egyre nagyobb felelősség hárul, ezért a magas szintü szakmai felkészültség nélkülözhetetlen. A médiával való kapcsolat valamennyi vállalatnál kiemelt helyen, érzékeny pontként jelent meg. Nyilvánvalóvá vált, hogy a kommunikációmenedzsmentet döntően befolyásolják

- a vállalat helyzetéből eredő belső hatások (például: költségtakarékosság, átszervezés),

- a kiemelt vállalatpolitikai cél vagy érték (például: innováció),

- az iparági hatások (például: egészségkockázat),

- az anyavállalat szervezeti kultúrája, az alkalmazott vezetési stílus,

- az a tény, hogy kontinenseken átívelő-e a tevékenység, vagy például csak Európára, vagy annak egyes országaira korlátozódik.

A standardizálás, illetve differenciálás mértékét jelentős mértékben meghatározza a globális, nemzetközi vállalat mérete. Minél nagyobb a vállalat, minél több országban van jelen, annál inkább standardizál.

\section{A kommunikációmenedzsment gyakorlati jelentösége}

A XX. század kutatói a vállalati kommunikációra túlnyomóan kétfunkciójú eszközként tekintettek. Egyrészt az információtovábbítás eszköze, amely elsősorban a vállalati vezetéstől visz instrukciókat, információt a dolgozóknak (jó esetben kétirányú). Másrészt a vállalati belső közösségépítés eszköze, amelynek köszönhetően belső kohézió alakul ki (Hübner, 2007).

A XXI. századi felfogásban a kommunikáció, mint fentebb bemutattuk, nem egyszerűen eszköz, hanem intangibilis, immateriális értékek hordozója és értékképző. A kutatások gyakorlati jelentősége kézzel foghatóvá vált:

- a kommunikáció tervezését a stratégiaalkotás szintjére emelte,

- a vállalati célok eléréséhez való hozzájárulást és a kommunikáció hatékonyságát bizonyítandó a hatékonyság mérésére szolgáló módszereket dolgozott ki,

- a vállalatoknál professzionálisan müködtetett kommunikációmenedzsment e tevékenységre specializálódott szakemberek alkalmazását, szakszolgáltatások igénybevételét eredményezte,

- kölcsönviszonyt hozott létre az ,új média” és annak vállalati alkalmazása között: a VKM új infokommunikációs technológia fejlesztésére inspirál, az új eszközök pedig új utakat, módszereket nyitnak meg a vezetés számára,

- komplexebbé tette a kommunikáció folyamatának kezelését (például az emberi kommunikáció kognitív és érzelmi komponenseire figyeléssel, amelyek alapvetően befolyásolják a tudásmegosztó, az innovációkommunikációt, az egyén motiváltságát),

- a globalizációval járó vallási, etnikai, faji, nemi értelemben vett diverzitás következménye, hogy a nyugati elméletekbe és a gyakorlatba keleti, sőt afrikai értékek, filozófiák és eljárások épülnek be és fordítva (példá- ul indiai nők megjelenése a munkaerő piacon, ezzel a vállalati kommunikáció színterén), és ezek megjelennek a vállalati kommunikációban,

- megnőtt a közösségi médiában, a vállalati valós párbeszédben való részvétel fontossága,

- az átláthatóság iránti elvárás kikényszeríti a transzparensség kommunikációját,

- a vállalatok társadalmi felelősségvállalásának monitorozása új tartalmi elemeket hozott a szervezetek és környezetük közti kommunikációban,

- a vállalati kommunikáció ,áramkör”-megközelítése dinamikus kölcsönhatásra összpontosít a küldo" és a befogadó között, hangsúlyozza a feedbacket, a kapcsolatot, „hálózatépítést” és „,kapcsolatok létrehozását” Clampitt (2001),

- működtetése egyszerre költségcsökkentő (idő-, eszköz- és humánerő-takarékos megoldások) és költségnövelö (szakemberigény).

\section{$A$ jövő várható útjai}

A VKM várható jövőbeni útjai a (kommunikációmenedzsment trendjeit, stratégiai témáit, gyakorlatát, eszközeit és forrásait kutató) European Communication Monitor (ECM) eredményei alapján a nemzetköziesedés, a globalizáció és a tömeg-, a digitális és a közösségi média hatása alatt formálódnak.

A 2007 óta évente elkészített ECM-kutatás szerint a kommunikációmenedzsmentben a jövőre vonatkozóan az alábbi trendek rajzolódnak ki:

- a kommunikációs eszközök és a csatornák további fejlödése,

- az interaktív csatornák (mint közösségi média, a hálózatok és online videók) jelentőségének további növekedése,

- a digitális fejlődéssel és a közösségi hálóval való birkózás,

- a fiatal generáció és a „mindig online” kommunikációs szakemberek megszólítása,

- digitális technológiai készségek csiszolódása,

- az információáradattal való megbirkózás,

- mobiltelefon applikációk és

- a tömegmédia jövőbeni relevanciája (Konczosné, 2016).

A hazai trendkutatásban, öt év vonatkozásában Szabó Lucian-Vasile 2014-es tanulmányában a következő, a kommunikációt érintő változásokat jelezte: 1) integrált elektronikus berendezések használata, 2) az összekapcsoltság általánossá válása, 3) a szolgáltatások és applikációk sokfélesége, 4) a felhőalapú számítógéphasználat széles körűvé és általánossá válása, 5) a tartalmakat közösen generáló és együtt építkező kommunikáció, 6) a kommunikáció óriási terület lesz, mivel az emberek az információcseréröl a szolgáltatások és termékek cseréjére fognak elmozdulni, 7) az etikai elvek minden összetevő tekintetében újraíródnak, az interperszonálistól a globálisig, beleértve a tömegkommunikációt és a közösségi médiát is (Szabó, 2014).

\section{Összefoglalás}

Tanulmányunk a vállalati kommunikációmenedzsmentet mint viszonylag új menedzsmentfunkciót vizsgálja mintegy harminc év távlatában. Négy pillérre épül: a keletkezés és önállósodás folyamata, a kutatási és alkalma- 
zási műhelyek és súlypontok létrejötte, a kutatott témák körei és gyakorlati jelentőségük, illetve a kirajzolódó jövő.

Az önálló fogalom megjelenéséből indul ki. Végigjárja a fogalom lehatárolódásának és az elnevezések tisztulásának zavaroktól nem mentes folyamatát. Érinti azokat a társadalmi hatásokat, a megnyíló technikai lehetöségeket, valamint a vezetéstudományi szemléletben bekövetkezett változásokat, amelyek kikényszerítették a vállalati kommunikáció alapvető megújulását, és mind a kutatásban, mind a gyakorlati alkalmazásokban gyökeres átalakulást, felértékelődést hoztak.

Bemutatjuk, hogy míg az amerikai kontinens az új diszciplína kialakulásban játszott döntő szerepet, addig az európai kutatók az általuk létrehozott iskolákban föként a VKM-ben rejlő lehetőségeknek, a továbbfejlesztés útjainak és az alkalmazásából eredő előnyöknek, a mérhető haszonnak a feltárásában jutottak kiemelkedő eredményekre és fejtettek ki ösztönző hatást.

A kutatott témák jól érzékelhető fókuszok körül szóródnak. Közöttük a menedzsmnet aktuális kérdéseit: az értékteremtést, az eredményesség mérését, a tanuló szervezetekben, illetve az innovációban játszott szerepet, az új média befolyásoló hatását és a nemzetközi és kultúraközi aspektust lehet azonosítani. A VKM kutatásának és professzionális alkalmazásának gyakorlati jelentősége nagyon széles területeken kézzel fogható: a stratégiaalkotástól kezdve, módszerfejlesztésen, komplexebb folyamatkezelésen, új tartalmi elemeken és eszközökön át a kommunikáció intenzitásának növeléséig megannyi eredmény ragadható meg.

A jövő várható trendjei a digitalizálódó világban felnőtt generációk szükségleteit és lehetőségeit vetítik előre a VKM területén is.

Tanulmányunk egy harminc év alatt nagy változásokon átment, ma még alig sejthető lehetőségeket magában hordozó vezetéstudományi terület képét vázolja fel.

\section{Felhasznált irodalom.}

Ablonczyné Mihályka, L., \& Tompos A. (2011). Az OPTICOM projekt kutatási tevékenységeinek bemutatása. In Borgulya Á. \& Deák Cs. (szerk.) Vállalati kommunikáció a 21. század elején (pp. 287 - 294). Miskolc: Z-Press.

Andersson, R. (2019). Employee Communication Responsibility: Its Antecedents and Implications for Strategic Communication Management. International Journal of Communication Management, 13(1), 60 - 75. DOI: https://doi.org/10.1080/1553118X.2018.1547731

Andres, S. (2004). Internationale Unternehmenskommunikation im Globalisierungsprozess. Wiesbaden.

Argenti, P. A. (2003). Corporate communication. New York: McGraw-Hill.

Bajzát T. (2011). Az interkulturális kompetencia elméletének és fejlesztésének legújabb eredményei, az idegennyelv-tudás és az interkulturális kompetencia vállalati elvárásai. In Borgulya Á., \& Deák Cs. (szerk.), Vállalati kommunikáció a 21. század elején (pp. 295 - 304.). Miskolc: Z-Press.

Bartsch, E. (Hrsg.) (1994). Sprechen, Führen, Kooperieren in Betrieb und Verwaltung. Kommunikation in Unternehmen. München, Basel: Reinhardt Verlag.
Beckett, R. C., \& Hyland, P. (2009). Effective communication in innovation processes. CINet, 96 - 106.https:// www.researchgate.net/publication/27483707 Effective communication_in innovation_processes, Letöltés: 2019. március 20.

Bentele, G. (1996). Public Relations. Bonn: ZV Zeitungsverlag Service.

Bentele, G., \& Will, M. (2006). Kommunikationsmanagement aus Sicht der Unternehmensführung. In Schmidt B. F. \& Lyczek B. (Eds.), Unternehmenskommunikation (pp. 149-181). Wiesbaden: Gabler.

Bentele, G., \& Nothhaft, H. (2010). Strategic Communication and the Public Sphere from an European Perspective. International Journal of Communication Management, 4(2), 93-116. DOI: https:/doi. org/10.1080/15531181003701954

Berger, R., Gärtner, H-D., \& Mathes, R. (1989). Unternehmenskommunikation. Grundlagen, Strategien, Instrumente. Wiesbaden/Frankfurter Allgemeine. Frankfurt am Main, Gabler.

Bhirud, S., Rodrigues, L., \& Desai, P. (2006). Knowledge Sharing Practices in KM: A Case Study In Indian Software Subsidiary. Journal of Knowledge Management Practice, Retrieved January 06, 2006: http://www.tlainc.com/articl103.htm.

Biesiadecka, G. M. (2009). Krisenpräventives Kommunikationsmanagement am Flughafen. Wiesbaden: VS Verlag für Sozialwissenschaften.

Birker, K. (1998). Betriebliche Kommunikation. Wiesbaden: Gabler Vlg.

Borgulya Á. (2008). Értékorientált kommunikációmenedzsment és kommunikáció-kontrolling. Vezetéstudomány, 30(11), $11-23$.

Borgulya, Á. (2010). Kommunikációmenedzsment a vállalati értékteremtésben. Budapest: Akadémiai Kiadó.

Borgulya, Á., \& Deák Cs. (szerk.) (2011). Vállalati kommunikáció a 21. század elején. Miskolc: Z-Press.

Borgulya, Á. (2011). A vállalatok nemzetközi kommunikációja. In Borgulya Á. \& Deák Cs. (szerk.), Vállalati kommunikáció a 21. század elején (pp. 171 - 188.). Miskolc: Z-Press.

Borgulya, Á. (2014). Kulturális távolságok-vállalatokon belüli és országok közötti interakciókban. Budapest: Typotex.

Borgulya, Á., Konczosné Szombathelyi, M., \& Szondi, Gy. (2015). Nemzetközi vállalatok országhatáron átívelő belső kommunikációjának menedzsmentje. Vezetéstudomány, 46(9-10). 12-24.

Borgulya, Á., Konczosné Szombathelyi, M., \& Fodor-Borsos E. (2016). Kommunikációmenedzsment-tanácsadás. In Poór, J. (szerk.) Menedzsment-tanácsadási kézikönyv. (24. fejezet, pp. 621-646). Budapest: Akadémiai Kiadó Zrt.

Borgulya, Á., \& Konczosné Szombathelyi, M. (szerk.) (2017). Vállalati kommunikációmenedzsment. Budapest: L'Harmattan Kiadó.

Borgulya, Á., \& Kovács, É. (2018). A klaszterkommunikáció és határterületei kutatásának kurrens témái: felvetések és bepillantás a szakirodalomba. Tér - Gazdaság-Ember. 2018. 2. szám, 67 - 87. 
Borgulya, Á., \& Balogh, G. (2019). Ipari klaszterek kommunikációja. Vezetéstudomány, 50(1), 29 - 42.

Bruhn, M. (1993). Effizientes Kommunikationsmanagement - Wandel und Perspektiven im Management der Marketing-Kommunikation. Webeforschung und Praxis, Heft 3., $75-86$.

Bruhn, M. (2003). Integrierte Unternehmens- und Marketingkommunikation. Stuttgart: Schäffer und Poeschl Verlag.

Bungarten, T. (Hrsg.) (1994a). Unternehmenskommunikation. Linguistische Analysen und Beschreibungen (= Beiträge zur Wirtschaftskommunikation, 4). Tostedt: Attikon.

Bungarten, T. (1994b). Die Sprache in der Unternehmenskommunikation. In Bungarten, T. (Hrsg.). Unternehmenskommunikation. Linguistische Analysen und Beschreibungen (= BWK, 4). (pp. 29-42.) Tostedt: Attikon.

Christensen, L. T. (1994a). Markedskommunikation som organiseringsmåde. En kulturteoretisk analyse. København: Akademisk Forlag.

Christensen, L. T. (1994b). Talking to Ourselves: Management through Auto-Communication. In MTC Kontakten, Jubiloeumstidsskrift, (pp. 32-37.) Stockholm, Marknadstekniskt Centrum.

Christensen, L. T., Morsing, M., \& Cheney, G. (2008). Corporate communications: Conventions, complexity, and critique. London: Sage Publications.

Clampitt, P.G. (2001). Communicating for Managerial Effectiveness. Thousand Oaks: Sage.

Cornelissen, J-P., \& Lock, A. R. (2001). The appeal of integration: managing communications in modern organizations, Marketing Intelligence \& Planning, 19(6), 425-431. DOI: https://doi.org/10.1108/ EUM0000000006110

Cornelissen, J. P., \& Wim, J-L. E. (2003). Managing corporate identity: an integrative framework of dimensions and determinants. Corporate Communications: An International Journal, 8(2), 114-120. DOI: https://doi. org $/ 10.1108 / 1356328031047553$

Cornelissen, J. (2008). Corporate communication. A guide to theory and practice. London: Sage.

Cornelissen, J. (2011). Corporate Communication: A Guide to Theory and Practice (3rd edition). Thousand Oaks: SAGE.

Crawford, Ch. B., \& Stronthkirch C. S., (2006). The Critical Role Communication in Knowledge Organizations: Communication apprehension as a predictor of Knowledge Management. Journal of Knowledge Management Practice, 7(4).

Cronquist, B., Johansson, L-O., \& Kjellin, H. (2006). Communication Enabling the Implementation of Innovation. http://www.diva-portal.org/smash/get/ diva2:239524/FULLTEXT01.pdf., letöltés: 2019. 01.21.

Culbertson, H. M., \& Chen, N. (1996). International public relations: A comparative analysis. London: Mahwah, N.J., Lawrence Erlbaum Associates.

Derieth, A. (1995). Unternehmenskommunikation. Eine theoretische und empirische Analyse zur Kommunikationsqualität von Wirtschaftsorganisationen. Wiesbaden: Westdeutscher Verlag.
Dobos, Cs. (szerk.) (2012). A vállalati kommunikáció interkulturális és nyelvészeti aspektusai. Miskolc: Miskolci Egyetem.

Drucker, P. F. (1969). The Age of Discontinuity. Guidelines to Our Changing Society. Oxford: ButterworthHeinemann.

Eppler, M. J. (2007). Knowledge Communication Problems between Experts and Decision Makers: an Overview and Classification. The Electronic Journal of Knowledge Management, 5(3), 291-300.

Esch, F. R., Langer, T., \& Bruhn, M. (Hrsg) (2016). Handbuch Controlling der Kommunikation. Grundlagen Innovative Ansätze - Praktische Umsetzungen. Wiesbaden: Springer Gabler.

Falkné Bánó K. (2011). Virtuális osztálytermi tréning (VCT) a jövő interkulturális tréningformája. In Borgulya Á. \& Deák Cs. (szerk.): Vállalati kommunikáció a 21. század elején (pp. 305 - 314.). Miskolc: Z-Press.

Feely, A., \& Harzing, A. W. (2003). Language Management in Multinational Companies. Cross Cultural Management: An International Journal, 10(2), 37-52. DOI: https://doi.org/10.1108/13527600310797586

Gelbmann, U., \& Vorbach, S. (2007). Das Innovationssystem. In Strebel, H., \& Gelbmann, U. (Hg.), Innovations- und Technologiemanagement (pp. 97-155.). Wien: WUV.

Grunig, J. E. (1992). Exellence in Public Relation Relations and Communication Management. Hillsdale: Erlbaum.

Grunig, J. E., \& Hunt, T. (1984). Managing Public Relations. New York: Holt, Rinehart and Winston.

Gümüs, M. (2007). The Effect of Communication on Knowledge Sharing in Organizations, Journal of Knowledge Management Practice, 8(2). http://www. tlainc.com/articl133.htm Letöltés. 2019. április 13.

Hallahan, K., Holtzhausen, D., van Ruler, B., Verčič, D., \& Sriramesh, K. (2007). Defining Strategic Communication. International Journal of Strategic Communication, 1(1). 3-35. DOI: http://dx.doi. org/10.1080/15531180701285244

Harlow, R.F. (1976). Bilding a Public Relations Definition. Public Relations Review, 2(4), 34 - 42. DOI: https:// doi.org/10.1016/S0363-8111(76)80022-7

Harzing, A.W., \& Feely, A. J. (2008). The language barrier and its implications for HQ-subsidiary relationships. Cross Cultural Management: An International Journal, 15(1), 49-61. DOI: https://oi. org/10.1108/13527600810848827

Harzing, A. W., Koster, K., \& Magner, U. (2011). Babel in business: The language barrier and its solutions in the HQ-subsidiary relationship. Journal of World Business, 46(3), 279-287. DOI: https://doi.org/10.1016/j. jwb.2010.07.005

Hering, R., Schuppener, B., \& Sommerhalder, M. (2004). Die Communications Scorecard. Bern, Stuttgart, Wien: Haupt Verlag.

Hidasi J. (2011). A globalizáció és a nemzetköziesedés vetületei. In Borgulya Á. \& Deák Cs. (szerk.), Vállalati kommunikáció a 21. század elején (pp. 189-200), Miskolc: Z-Press. 
Hildebrandt, H. W., \& Liu, J. (1991). Communication through foreign languages: An economic force in Chinese enterprises. Journal of Asian Pacific Communication, 2(1), 45-67.

Hoffmann, K. (2001). Das Intranet. Ein Medium der Mitarbeiterkommunikation. Konstanz: UVK.

Huck, S. (2005a). Internationale Unternehmenskommunikation. Stuttgart. URL. http:/opus.uni-hohenheim.de/ volltexte/2005/102/

Huck, S. (2005b). Internationale Unternehmenskommunikation: Ergebnisse einer qualitativen Befragung von Kommunikationsverantwortlichen in 20 multinationalen Großunternehmen. URN: urn: nbn:de:bsz:100-opus-1027 URL: http://opus.uni-hohenheim.de/volltexte/2005/102/

Huck, S. (2006). Internationale Unternehmenskommunikation. In Mast, C. (Hrsg.), Unternehmenskommunikation. Ein Leitfaden (Zweite bearbeitete und erweiterte Auflage) (pp. 369 - 387). Stuttgart: Lucius und Lucius Verlag.

Huck, S. (2007). Internationale Unternehmenskommunikation. In Piwinger, M., \& Zerfass, A. (Hrsg.), Handbuch Unternehmenskommunikation (pp. 891-904). Wiesbaden: Verlag Gabler| GWV Fachverlage GmbH.

Huck, S. (Hrsg) (2007). Innovationskommunikation: Innovationen verständlich vermitteln: Strategien und Instrumente der InnovationskommunikationReihe: Kommunikation \& Analysen Band 3. Stuttgart: Universität Hohenheim.

Huck-Sandhu, S., \& Hassenstein, K. (Hrsg.) (2013). Innovation - Kommunikation - Management (Reihe Kommunikationsmanagement, Band 01). Pforzheim: Hochschule Pforzheim.

Hübner, H. (2007). The Communicating Company: Towards an alternative theory. Physica Verlag.

Johanssen, K. P. (2001). Lokal oder global - ist das die Frage? In Johanssen, K. P., \& Steger, U. (Hrsg.), Lokal oder Global? Strategien und Konzepte von Kommunikations-Profis für internationale Märkte (pp. 42-75). Frankfurt a. M., S.

Kirchner, K. (2001). Integrierte Unternehmenskommunikation. Theoretische und empirische Bestandsaufnahme und eine Analyse amerikanischer Großunternehmen. Wiesbaden: Westdeutscher Verlag.

Klewes, J. (Hrsg.) (2005). Unternehmenkommunikation auf dem Prüfstand. Wiesbaden: Deutscher Universitätsverlag.

Klare, J. (2010). Kommunikationsmanagement deutscher Unternehmen in China. Wiesbaden: VS Verlag für Sozialwissenschaften. GWV Fachverlage.

Konczos Szombathelyi, M. (2008). Kommunikáló kultúrák. A töketelepités nyelvi és kulturális infrastruktúrája, avagy a kultúraközi kommunikáció néhány aspektusa. Budapest: L'Harmattan Kiadó.

Konczosné Szombathelyi, M. (2013). Modern elméletek és globális trendek a kommunikációmenedzsmentben. Tér-Gazdaság-Ember, 1(4), 9-26. http://kgk.sze.hu/ images/dokumentumok/folyoirat/TGE_I_evf_04.pdf

Konczosné Szombathelyi M., Waldbuesser, P., \& Tench, R. (2015). Digital age: Information and communication technologies, tools and trends for communication management. In Baranyi P. (ed.), 6th IEEE Conference on Cognitive Infocommunications CogInfoCom 2015 Proceedings (pp. 229-234). Győr: Széchenyi István Egyetem.
Konczosné Szombathelyi, M. (2016). Generációk és infokommunikációs technológiák használata az európai kommunikációs szakemberek körében. In Lőrincz I. (szerk.), XIX. Apáczai-napok Nemzetközi Tudományos Konferencia, Gondolkodási struktúrák és kreativitás (Tanulmánykötet) (pp. 81-89). Györ. http://publicatio.nyme.hu/1358/1/ Forintositasi_technikak_Apaczai_napok_u.pdf

Konczosné Szombathelyi, M., Borgulya Á., \& Szondi Gy. (2016). Managing Cross-border Intern Corporate Communication of International Companies. Organizaciju Vadyba, Systeminiani Tyrimai. Management of Organizations: Systematic Research, 75, 71-82. DOI: http://dx.doi.org/10.7220/MOSR.2335.8750.2016.75

Könighofer, D. (2013). Innovationskommunikation. http:// othes.univie.ac.at $/ 3010$

Lautenbach, Ch., \& Sass, J. (2005). Internationale Perspektiven des Kommunikations-Controllings. In Pfannenberg, J., \& Zerfass, A. (Hrsg), Wertschöpfung durch Kommunikation (pp. 36 - 45). Frankfurt am Main: Frankfurter Allgemeine Buch.

Lesko, Ch.J., \& Hollingsworth, Y. A. (2011). A New Approach to Communications Management Planning Through 3D Web and Semantic Web Technologies. Journal of Management and Strategy, 2(3), September 2011. www.sciedu.ca/jms

Liebl, Ch. (2003). Kommunikations-Controlling: Ein Beitrag zur Steuerung der Marketing-Kommunikation am Beispiel der Marke Mercedes-Benz (Wirtschaftswissenschaften). Wiesbaden: Deutsche Universitäts-Verlag.

Luo, Y. (2007). From foreign investors to strategic insiders: Shifting parameters, prescriptions and paradigms for MNCs in China. Journal of World Business, 42(1), 14-34. DOI: https://doi.org/10.1016/j.jwb.2006.08.009

Maas, W., \& Stahl, F. (2008). Contentmanagement als Teil des Kommunikationsmanagement. In Meckel, M., \& Schmid, B.F. (Hrsg.). Kommunikationsmanagement im Wandel: Beiträge aus 10 Jahren (pp. 151-163). Wiesbaden: Gabler Vlg.

Magnuczné Godó, Á. (2016). Belső vállalati kommunikáció, gyakorlat, hatékonyság, problémák és megoldások. Alkalmazott Nyelvészeti Közlemények, 11(1), 72-82.

Mast, C. (2002). Unternehmenskommunikation. Stuttgart: Lucius at Lucius Verlag.

Mast, C. (2005a). Werte schaffen durch Kommunikation: Was von Kommunikationsmanagern erwartet wird? In Pfannenberg, J.\& Zerfass, A., (Hrsg), Wertschöpfung durch Kommunikation (pp. 27 - 35). Frankfurt am Main: Frankfurter Allgemenine Buch.

Mast, C. (2005b). Unternehmenskommunikation in der Wertschöpfungskette - Aktuelle Herausforderungen aus der Sicht der DAX-Unternehmen. In Klewes, J. (Ed.), Unternehmenskommunikation auf dem Prüfstand (pp. 1-18). Wiesbaden: Deutscher UniversitätsVerlag/GWV Fachverlage GmbH.

Mast, C. (2009). Mitarbeiterkommunikation, Change und Innovationskultur. Balance von Informationen und Innovationen. In Zerfass, A., \& Möslein, K. (Hrsg.), Kommunikation als Erfolgsfaktor im Innovationsmanagement. Strategien im Zeitalter der Open Innovation (pp. 271-288). Wiesbaden: Gabler. 
Mast, C., \& Fiedler, K. (2004). Mitarbeiterzeitschriften im Zeitalter des Intranet. Ergebnisse einer Umfrage bei Banken und Versicherungen. Kommunikation \& Management. Band 5. Stuttgart: Universität Hohenheim.

Mast, C., Huck, S. \& Zerfass, A. (2005). Innovation Communication. Outline of the Concept and Empirical Findings from Germany. Innovation Journalism, 2(7), May 13, www.innovationjournalism.org

Meckel, M., \& Schmid, B.F. (Hrsg.) (2008). Kommunikationsmanagement im Wandel: Beiträge aus 10 Jahren (pp. 340 - 367). Wiesbaden: Gabler Vlg.

Moreno, A., Verhoeven, P., Tench, R., \& Zerfass, A. (2010). European Communication Monitor 2009. An institutionalized view of how public relations and communication management professionals face the economic and media crises in Europe. Public Relations Review, (36), 97-104. DOI: https://doi.org/10.1016/j.pubrev.2010.02.004

Muhr, R. (1988). Kommunikationsprobleme in komplexen Industriebetrieben. In von Bungarten, T. (Hrsg.), Sprache und Information in Wirtschaft und Gesellschaft (pp. 308-332). Hamburg: Tostedt, Attikon.

Nelke, A. (2016). Kommunikation und Nachhaltigkeit im Innovationsmanagement von Unternehmen. Wiesbaden: Springer-Verlag.

Oelert, J. (2003). Internes Kommunikationsmanagement: Rahmenfaktore, Gestaltungsansätze und Aufgabenfelder. Wiesbaden: Deutscher Universitätsverlag.

O’Gorman, S., \& Pirner, P. (2005). Messen und monitoren von Stakeholder-Beziehungen: Der TRIM-Index. In Pfannenberg, J., \& Zerfass, A. (Hrsg), Wertschöpfung durch Kommunikation (pp. 48 - 59). Frankfurt am Main: Frankfurter Allgemeine Buch.

Park, S. H., \& Vanhonacker, W. R. (2007). The challenge for multinational corporations in China: Think local, act global. MIT Sloan Management Review, 48(4), 7-15. https://www.researchgate.net/profile/Seung Park8/publication/271199219_The_Challenge_for Multinational_Corporations_in_China_Think_Global_Act_Local/links/5590b81108ae1e1f9̄bae2875.pdf

Pfannenberg, J. (2005). Kommunikations-Controlling im Value Based Management: Die monetäre Wertschöpfung von Kommunikation. In Pfannenberg, J., \& Zerfass, A. (Hrsg). Wertschöpfung durch Kommunikation (pp. 132141). Frankfurt am Main: Frankfurter Allgemeine Buch.

Pfeffermann, N., \& Hülsmann, M. (2011). Communication of Innovation: Marketing, Diffusion, and Frameworks. In Hülsmann, M., \& Pfeffermann, N. (Hrsg.), Strategies and Communications for Innovations: An Integrative Management View for Companies and Networks (pp. 97-104). Berlin, Heidelberg: Springer.

Piwinger, M., \& Zerfass, A. (Hrsg.) (2007). Handbuch Unternehmenskommunikation. Wiesbaden: Gabler.

Porák, V., Fieseler, Ch., \& Hoffmann, Ch. (2007). Metoden der Erfolgsmessung von Kommunikation. In Piwinger, M., \& Zerfass, A. (Hrsg.), Handbuch Unternehmenskommunikation (pp. 535-556). Wiesbaden: Gabler Verlag.

Primecz, H., Romani, L., \& Sackmann, S. (2011). CrossCultural Management in Practice: Culture and Negotiated Meanings. Cheltenham: Edward Elgar Publ.
Rolke, L. (2005). Kennnziffernsystem für die wertorientierte Unternehmenskommunikation: CommunicationControlCockpit (CCC). In Pfannenberg, J., \& Zerfass, A. (Hrsg), Wertschöpfung durch Kommunikation (pp. 123-131). Frankfurt am Main: Frankfurter Allgemeine Buch.

Rolke, L. (2007). Kennzahlen für die Unternehmenskommunikation. In Piwinger, M., \& Zerfass, A. (Hrsg.), Handbuch Unternehmenskommunikation (pp. 575586). Wiesbaden: Gabler Verlag.

Röhrig, S. (2005). Wertschöpfung durch Kommunikation im Bereich DaimlerChrysler Classic. In Pfannenberg, J. \& Zerfass, A. (Hrsg.), Wertschöpfung durch Kommunikation (pp. 142-154). Frankfurt am Main: Frankfurter Allgemeine Buch.

Röttger, U., Zerfass, A., Kiesenbauer, J., \& Stahk, J. (2013). Führung in Kommunikationsmanagement Herausförderung im internationalen Vergleich. Forschungsberichte zur Unternehmenskommunikation. Nr. 1. Leipzig, Akademische Gesellschaft für Unternehmensführung und Kommunikation.

Salis, S., Williams, \& A. M. (2008). Knowledge Sharing Through Face-To-Face Communication and Labour Productivity: Evidence from British Workplaces. https://pdfs.semanticscholar.org/4e2f/1ccc779052a466 8cd10c5596509blef95f9f.pdf

Schmid, B.F, \& Lyczek, B. (2006). Die Rolle der Kommunikation in der Wertschöpfung der Unternehmung. In Schmid, B. F. \& Lyczek, B. (Hrsg), Unternehmneskommunikation (pp. 3-146). Wiesbaden: Gabler/GWV Fachverlage.

Schmid, B.F., \& Lyczek, B. (Hrsg) (2006). Unternehmenskommunikation. Kommunikationsmanagement aus Sicht der Unternehmensführung. Wiesbaden: Gabler/ GWV Fachverlage.

Schmid B.F., \& Meckel M. (2008). Kommunikationsmanagement in der Symbolgesellschaft. In: Meckel M., \& Schmid B.F. (Eds.), Kommunikationsmanagement im Wandel. Wiesbaden: Gabler.

Schuppener, B. (2005). Erfolgreiche Steuerung und Bewertung von Kommunikation: Die Communication Scorecard. In Pfannenberg, J., \& Zerfass, A. (Hrsg), Wertschöpfung durch Kommunikation (pp. 113-121). Frankfurt am Main: Frankfurter Allgemeine Buch.

Siano A., Vollero A., Confetto M.G., \& Siglioccolo M. (2013). Corporate communication management: A framework based on decision making with reference to communication resources. Journal of Marketing Communications, 19(3), 151-167. DOI: https://doi.org/ $10.1080 / 13527266.2011 .581301$

Sriramesh, K., \& Verčič, D. (Eds.) (2003). The Global PR Handbook. Theory, Research and Practice. London, Mahwah, NJ: Laurence Erlbaum Associates.

Sriramesh, K., \& Verčič, D. (Eds.) (2009). The Global Public Relations Handbook: Theory, Research and Practice. New York: Routledge.

Steyn, B. (2003). From strategy to corporate communication strategy: a conceptualisation. Journal of Communication Management, 8(2), 168-183. DOI: https://doi. org/10.1108/13632540410807637 
Szabó, L. V. (2014). The Future of Communication: From New Media to Postmedia Procedia. Social and Behavioral Sciences, 163, 36-43. DOI: https://doi. org/10.1016/j.sbspro.2014.12.283

Szőrös, K. (2008). Stratégiai mutatószámrendszerek a vállalati kommunikációban. In Radványi T. (szerk.), Üzlet és Tudomány: Dolgozatok a Pénzügyi és Számviteli Föiskolai Kar tudományos mühelyéböl (pp. 97104). Magyar Tudomány Napja, Budapest, 2008.11.062008.11.07. Budapest: BGF.

Szőrös, K. (2010a). A szervezeti kommunikáció controlling szempontú megközelítései. In Papp-Váry, Á., \& Csépe, A. (szerk.), Új marketing világrend MOK 2010 (pp. 503-517.), Magyar Marketing Szövetség Marketing Oktatók Klubja 16. országos konferenciája. Budapest: Budapesti Kommunikációs és Üzleti Főiskola.

Szörös, K. (2010b). A controlling koncepció megjelenése a szervezeti kommunikáció menedzselésében. In Bencsik, A. (szerk.), Tanulás, tudás, gazdasági sikerek (pp. 141-147). Győr: Széchenyi István Egyetem.

Talke, K. (2005). Einführung von Innovationen. Wiesbaden: Dt. Universitatsverlag.

Tench, R., \& Yeomans, L. (2017). Exploring Public Relations (4th eds.). Harlow: Pearson.

Ybema, S., \& Hyunghae, B. (2009). Cultivating Cultural Differences in Asymmetric Power Relations. International Journal of Cross Cultural Management, 9(3), 339358. DOI: https://doi.org/10.1177/1470595809346600

Vaara, E., Tienari, J., Piekkari, R., \& Säntti, R. (2005). Language and the circuits of power in a merging multinational corporation. Journal of Management Studies, 42(3), 2362-2380. http://www.blackwell-synergy.com DOI: https:doi.org//doi/abs/10.1111/j.1467-6486.2005.00510.x

Van Riel, C. B. (1992). Principles of Corporate Communication. Hemel Hempstead: Prentice-Hall.

Van Riel, C. B. (1995). Principles of corporate communication. Hemel Hempstead: Prentice- Hall.

Van Riel, C. B., \& Fombrun, C. J. (2007). Essentials of corporate communication: Implementing practices for effective reputation management. London: Routledge.

Van Ruler, B., \& Verčič, D. (2005). Reflective communication management. Future ways for public relations research". In International Communication Association (Ed.) Communication Yearbook 29, (pp. 239-273). New Brunswick, NJ: Translation Books.

Varey, R. J. (1998). Locating marketing within the corporate communication managing system. Journal of Marketing Communications, 4(2), 177 -190. DOI: https://doi.org/10.1080/135272698345834

Varey, R. J., \& White, J. (2000). The Corporate Communication System of Managing. Corporate Communications: An International Journal, 5(1), 5-11. DOI: https:// doi.org/10.1108/13563280010317523

Verčič, D., Jugo, D., \& Ciboci, L. (Eds.) (2015). Reconciling the Traditional and Contemporary: The New Integrated Communication. Zagreb: Edward Bernays College of Communication Management.
White, J. \& Dozier, D.M. (1992). Public relations and management decision-making. In Grunig, J. E. (Ed.), Excellence in public relations and communications management. Hillsdale, New Jersey: Lawrence Erlbaum Associates.

Wiedman, K. P., Fombrun, Ch. J., \& Riel, C.B.M. (2005). Reputation messen und vergleichen. Der Reputation Quotient. In Pfannenberg, J., \& Zerfass, A. (Hrsg), Wertschöpfung durch Kommunikation (pp. 48-59). Frankfurt am Main: Frankfurter Allgemeine Buch.

Witt, F. J (1993). Managerkommunikation. Stuttgart: Schäffer-Poeschel Verlag.

Zerfass, A. (1996). Unternehmensführung und Öffentlichkeitsarbeit. Grundlegung einer Theorie der Unternehmenskommunikation und Public Relations. Opladen: Westdeutscher Verlag

Zerfass, A. (2005). Integration von Unternehmenszeielen und Kommunikation: Die Corporate Communications Scorecard. In Pfannenberg, J., \& Zerfass, A. (Hrsg), Wertschöpfung durch Kommunikation (pp. 102-113). Frankfurt am Main: Frankfurter Allgemeine Buch.

Zerfass, A. (2009). Kommunikation als konstitutives Element im Innovationsmanagement. Soziologische und kommunikationswissenschaftliche Grundlagen der Open Innovation. In Zerfass, A., \& Möslein, K. (Hg.), Kommunikation als Erfolgsfaktor im Innovationsmanagement. Strategien im Zeitalter der Open Innovation (pp. 23-49). Wiesbaden: Gabler.

Zerfass, A., \& Pfannenberg, J. (2005). KommunikationsControlling: Neue Herausforderungen für das Management. In Pfannenberg, J. \& Zerfass, A. (Hrsg), Wertschöpfung durch Kommunikation (pp. 14-26, pp. 27-35). Frankfurt am Main: Frankfurter Allgemenine Buch.

Zerfass, A., \& Huck, S. (2007). Innovation, Communication and Leadership. New Developments in Strategic Communication. International Journal of Strategic Communication, 1(2), 107-122. DOI: https://doi. org/10.1080/15531180701298908

Zerfass, A., \& Nadin, E. (2008). Kommunikation als Erfolgsfaktor im Innovationsmanagement. Ergebnisse einer Studie in deutschen Zukunftstechnologie -Branchen. Leipzig: Universität Leipzig.

Zerfass, A., \& Möslein, K. (2009). Kommunikation im Innovationsprozess. Thesen füreine effektive Zusammenarbeit. In Zerfaß, A., \& /Möslein, K. (Hg.), Kommunikation als Erfolgsfaktor im Innovationsmanagement. Strategien im Zeitalter der Open Innovation (pp. 417-422). Wiesbaden: Gabler.

Zerfass, A., Tench, R., Verhoeven, P., Verčič, D., \& Moreno, A. (2018). European Communication Monitor 2018. Strategic communication and the challanges of fake news. trust, leadership, work stress and job satisfaction. Results of a survey in 48 countries. Brussels. EACD EUPRERA. Quadriga Media Berlin.

Zhang L.E., Harzing A. W., \& Fan S.X. (2018). Host Country Language: Why It Matters, and Why Expatriates Need to Learn It. In Managing Expatriates in China. Palgrave Studies in Chinese Management (pp. 55-89). London: Palgrave Macmillan. 